\title{
THE FOREIGN DIRECT INVESTMENT REGULATIONS: A EUROPEAN LEGAL POINT OF VIEW
}

\author{
ECKARD REHBINDER*
}

\section{INTRODUCTION}

Since the beginning of I968, American firms with foreign interests have had to live with a mandatory program that restrains direct investment abroad in order to reduce the growing U.S. balance of payments deficit and to restore confidence in the dollar as a stable world trading, investment, and reserve currency. The main features of this program, introduced by Executive $\operatorname{Order}^{1}$ and implemented by the Foreign Direct Investment Regulations, ${ }^{2}$ are restrictions on capital transfers from U.S. direct investors (DIs) to affiliated foreign nations (AFNs) and on reinvestment of earnings of AFNs and limitations on the amount of liquid foreign balances of DIs. ${ }^{3}$ These restrictions originally met with strong criticism by those directly affected. Indeed, the regulations, especially in the first months of their existence, seemed to and often did cause uncertainties, difficulties, hardships, and inequities for some DIs; and they compelled a reorientation of foreign investment policies for all of them. In the meantime, DIs have become accustomed to the restrictions; the extent of cooperation with the Office of Foreign Direct Investments of the Department of Commerce (OFDI), delegated responsibility to administer the program, has been high. One of the reasons for that is no doubt the rapid growth of the Eurodollar market ${ }^{4}$ and the high liquidity of the European national capital and credit markets, which enabled the DIs to raise capital abroad at rates competitive with those in the U.S. Another reason is the pragmatic approach of OFDI in the administration of the program. While insisting on its task to administer the program as effectively as possible, OFDI has promulgated a series of clarifying and modifying amendments to the regulations and has issued a significant number of specific authorizations which

- Dr. jur., Frankfurt, 1965 . Professor of Law, University of Bielefeld.

The author wishes to express his appreciation for the helpful comments of Patrick Heininger, an American Fellow at the Institut für ausländisches und internationales Wirtschaftsrecht in Frankfurt.

${ }^{1}$ Exec. Order No. II 387,33 Fed. Reg. 47 (I968).

a 15 C.F.R. pt. $1000(1969)$. These regulations are cited hereinafter as OFDI Reg. $\S —$, omitting from each section reference the prefix "I000" (e.g., $\$ 1000.306$ ) which it bears in the Code of Federal Regulations.

${ }^{3}$ For a description of the functioning of the regulations with regard to Western Europe and an appraisal of their impact on these countries from a purely American point of view, with emphasis on the tax consequences, see Kingson, Investment in Western Europe Under the Foreign Direct Investment Regulations: Repatriation, Taxes and Borrowings, 69 Colum. L. Rev. I (I969).

"For a general description' of the functioning of the Eurodollar market, see P. Einzig, The EuroDollar System (1967); Euro-Dollar Financing, A Guide for Multi-National Companies (Chase Manhattan Bank, 1968); Gwinner, Growth and Spasms in the Eurobond Market, Financial Times, April 8, I969, at I4. 
have relieved DIs of some of the inequities and hardships caused by the regulations. Finally, the over-all liberalization of the mandatory program initiated by the new administration has given DIs more flexibility in their foreign investment policy.

For an American observer, the effects of the regulations on the U.S. balance of payments problems and on the foreign investment potential and behavior of American DIs are of overriding significance. However, the foreign direct investment regulations have a foreign impact, too. This is particularly true of the restrictions on reinvestment and the corresponding (implied) obligation of DIs to repatriate that portion of their AFNs earnings which may not be reinvested. For it is reinvestment of earnings of business entities subject to foreign law with which the regulations are concerned; it is reinvestment in foreign countries of earnings derived from foreign countries which is affected by the regulations. Certainly the regulations are not directly applicable to any foreign national. They only apply to the American DI who is required to repatriate that portion of the earnings of its AFNs which does not constitute allowable reinvestment. The regulations do not even pertain (nor are they "indirectly" applicable) to a single foreign national since they do not operate on a company-by-company basis but rather on a schedule-of-countries, or in some instances even a worldwide, basis. The fact remains, however, that the regulations have the intended effect ${ }^{6}$ of limiting the reinvestment possibilities, and of compelling the repatriation of a substantial portion of the earnings of foreign business entities over which the DI has control. (Absent such control it can only be expected to make a bona fide attempt and, in case of failure, shift the repatriation burden to its other AFNs in the same scheduled area; $;^{7}$ these cases are of minor interest in our context and need not be discussed further.) The schedule-of-countries approach only affords the DI the opportunity to shift the repatriation burden, or at least a part of it, from one AFN to another, not more. Finally, it is not the applicable foreign law but rather U.S. accounting principles ${ }^{8}$ that determine the computation of earnings and hence the extent of the repatriation obligation.

It follows that foreign interests, both private and public, are vitally concerned with the foreign direct investment regulations. The problem of the possible effects of the regulations on foreign countries, their political and economic interests, their legal order, and the private interests of their citizens, has already been given some attention in the U.S. During last year's congressional hearings, Dr. Danielian pointed out that the regulations did not give consideration "to the legal requirements in other countries concerning calculation or authorization of dividends," and that the regula-

\footnotetext{
${ }^{5}$ OFDI Reg. $\S 20 I(a)$; $c f$. OFDI General Bulletin No. I, Interpretative Analyses and Statements $\S$ B306, 33 Fed. Reg. 15158, 15172 (1968) [hereinafter cited as Gen. BuLl. No. I].

'Bruck \& Lees, Foreign Investment, Capital Controls, and the Balance of Payments, 48-49 'Tue BulletrN 8, 62 (New York University, Graduate School of Business Administration, Institute of Finance, 1968).



${ }^{8}$ Id. $\$ \mathrm{~B}_{3} 06(\mathrm{c})$.
} 
tions did not provide for an exemption where a company was unable to comply because local law protected minority shareholders. ${ }^{9}$ OFDI also recognized that the repatriation of earnings of a particular AFN may not be feasible or may result in substantial hardship due to legal barriers, objections by minority shareholders, or contractual restrictions on the payment of dividends; it advised the DIs to compensate therefor by causing other AFNs not affected by these problems to pay higher dividends, or to use the proceeds of foreign borrowings. ${ }^{10}$

Moreover, many others, including members of the House of Representatives, warned against possible retaliatory measures that might be taken by host countries unfavorably affected by the regulations. ${ }^{11}$ A statement made by Representative Edwards of California in a House debate on September I7, I968, is illustrative. Mr. Edwards stated:

US affiliates abroad are legally local companies and cannot be used as tools of US foreign economic policy without eventual retaliation. ...

The mandatory program with respect to direct investment, as the voluntary program before it, has announced to the world that the US government regards these companies even though incorporated under a foreign jurisdiction as American companies. ${ }^{12}$

He continued that the U.S. thereby had officially expressed its view "that the operations of these companies must be conducted subject to the overriding needs of U.S. foreign economic policy."

One might wonder why this American criticism has not, as yet, been paralleled by an equally strong concern in Continental Europe, the schedule $\mathrm{C}$ area whose economy is affected most by the regulations. True, the Spanish and French governments voiced objections to the regulations, the French government even hinting at the possibility that it might revoke the admission of U.S.-controlled subsidiaries to the French capital market. ${ }^{13}$ But with the rapid growth of the Eurodollar market and the absence of serious negative effects of the regulations on national capital and credit markets the French resistance faded away. The government of the Federal Republic of Germany even expressed its appreciation of the U.S. "political efforts to reduce the deficit in the U.S. federal budget," which were regarded as a less burdensome alternative to "measures which might favor a revival of protectionist trends in the world"14 (i.e., restrictions on German imports to the U.S.). Neither has the

\footnotetext{
'Hearings on the Administration's Balance-of-Payments Proposals Before the House Comm. on Ways and Means, 9oth Cong., 2d Sess., pt. 2, at 830-3I, 835 (I968).

${ }^{10}$ Gen. BULL. No. $x, \S 306(\mathrm{e})$.

${ }^{11}$ See statements by $\mathrm{J}$. Seath, in Hearings, supra note 9, at 585 ; by L. Hamilton, id. at 589 ; by C. Stewart, id. at 6r9; by N. R. Danielian, id. at 8I2; by Represenative Thompson, II4 CoNG. REc. H8826 (daily ed. Sept. I7, I968); by Represenative Edwards, id. at H8828.

${ }^{13}$ II 4 Cong. Rec. H8828 (daily ed. Sept. I7, I968).

${ }^{23}$ See "Call to Repatriate Overseas Earnings Stirs Legal Snarls," N.Y. Times, Jan. 29, I968.

Is Statement by K. Schiller, Minister of Economic Affairs and Governor of the Bank for Germany, at the Joint Annual Discussion, Boards of Governors, International Monetary Fund, International Bank for Reconstruction and Development, Press Release No. I7, at 2-3 (Oct. I, I968).
} 
European business community, including the domestic members of the boards of U.S.-controlled subsidiaries directly affected, had very many objections to the application of the regulations to the reinvestment decisions of these European business entities.

In this state of affairs, one may wonder whether an appraisal of the regulations from a European legal point of view is necessary at all. I think such an appraisal should be undertaken for three reasons: First, much of the reserve of European governments and, even more, of the business community is due to the expectation that the regulations will be only a temporary measure. Since, in view of the U.S. balance of payments situation, even the new administration was not able to completely abolish the controls but only to liberalize them, it becomes more and more difficult to consider them as a short-range expediency to cope with a crisis situation. ${ }^{16}$ That will have an effect on their future evaluation in Europe. Second, the present European appraisal of the restrictions is based on present conditions of European capital and credit markets. If the massive demand of U.S. firms on these markets unfavorably affects market conditions, ${ }^{16}$ the reaction of Europeans might change. Third, the restrictions raise questions of principle which will remain significant even after an ultimate dismantling of the network of direct controls.

This paper will present mainly a German legal point of view of the foreign direct investment regulations, particularly the reinvestment provisions. But in view of the schedule approach of the regulations I will add some remarks on the legal situation in France, the schedule C country which, after West Germany, has the highest U.S. direct investment.

\section{I}

\section{Conflicts Between European Corporation Law and the Regulations}

\section{A. The Potentiality for Conflict}

As has already been pointed out, the regulations restrict reinvestment of earnings of European business entities which, though U.S.-controlled, are subject to the local law (in general, the law of their principal place of business). Since both laws regulate (in the case of the U.S. controls, at least de facto) the internal affairs of the same business entity, conflicts between them seem unavoidable. Of all the various types of business entities in Europe, this is specially true with regard to the largely mandatory law of corporations. The following discussion will be limited to corporations, by far the most important among all U.S.-controlled business entities.

Under European conflict of laws rules, it is clear that local corporation law

\footnotetext{
${ }^{15}$ Cf. statement by Rep. Tunney, II 4 Covg. Rec. H882I (daily ed. Sept. 17, I968).

${ }^{16}$ For trends in this direction, see Brestel, Der Euro-Markt-ein modernes Kapitalmarkttutnder, Frankfurter Allgemeine Zeitung, Jan. Ir, 1969, at 20; Tumiati, Further Italian Curbs on Capital Movements, Financial Times, April 8, 1969, at 7.
} 
has priority over the regulations. Mandatory provisions concerning the functioning of a local corporation and the protection of its shareholders and creditors are applicable without regard to the nationality of the majority shareholder or parent corporation. ${ }^{17}$ And although the regulations do not contain a specific exemption, it is the practice of OFDI not to compel any DI to violate the local corporation law. ${ }^{18}$ Theoretically, therefore, a conflict does not exist. In reality, however, conflicts may result from the uncertainties and lacunae in European corporation law. A foreign law barrier to repatriation does not automatically relieve the DI of the repatriation obligation. OFDI expects the DI to compensate therefor by causing other AFNs in the same scheduled area not affected by the barrier to pay additional dividends, by causing AFNs to make additional transfers of capital, or by using proceeds of foreign borrowing. If OFDI recognizes that there is no practical alternative to the payment of dividends it will grant an exemption but will require the DI to "mortgage" its future investment in the schedule affected by the legal barrier." The undesirability of these alternatives may have the practical result that the DI is forced to make full use of the uncertainties and lacunae of the local corporation law, to evade it, or even openly to violate it, relying on the inaction of the board of the subsidiary, which might not dare to oppose this policy, and of the minority shareholders, who might not be able to do so. To this extent, a real conflict exists, or may exist.

This problem arises in particular, though not exclusively, ${ }^{20}$ with regard to the legal protection of minority shareholders. The crucial question here is whether and to what extent the DI, in complying with the regulations, can cause the board or the shareholders' meeting of the European subsidiary to determine its reinvestment policy according to the DI's repatriation obligation rather than according to their business judgment as required under European corporation law. But one should not overemphasize the significance of this problem. Only the smaller part of U.S.controlled subsidiaries in France and West Germany have to deal with minority interests. The majority are wholly-owned subsidiaries. ${ }^{21}$ Moreover, the gradual

${ }^{17}$ H. Soergel \& W. Siebert, Bürgerliches Gesetzbuch, art. xo EGBGB nn. 5, 19-2I (9th ed. Kegel, I96r), and the cases cited therein; M. WolfF, Das internationale Privatrecht Deutschilands II 7 (3d ed. 1954); H. Würdinger, Aktien- und Konzernaecirt 19-22 (2d ed. x966); H. Batiffor, Trait'́ ÉléNentaIre DE DROIT INTERNATIONAL PRIVte No. 203 (4th ed. 9967 ).

${ }^{18}$ GeN. BuLl. No. $x, \S B 306$.

${ }^{10} \mathrm{Id}$.

${ }^{30}$ There are some other areas of possible conflict or inconsistency, such as the computation of earnings both for the base period and the year, which result from divergencies in accounting principles (undervaluation, legal reserve), the computation of the DI's share in the earnings (payment of preferred dividends), or the legal effect of mandatory reinvestment (legal reserve) on the repatriation obligation. But these problems partly involve no true conflicts since the application of U.S. accounting principles does not compel the AFN to change its methods of accounting and computation of earnings; party they are of minor significance, at least after the over-all liberalization of the mandatory program and the issuance by OFDI of various clarifying amendments and of GEN. BuLL. No. I.

${ }^{21}$ In Germany, more than $50 \%$ of the U.S.-controlled stock corporations and roughly $70 \%$ of the 
liberalization of the mandatory controls in 1968 and especially in 1969 with the substantial departure from the base period formula and the granting of a much higher minimum investment quota have expanded, or will expand in future, the reinvestment potential of AFNs and thereby reduce the possibility of objections by minority shareholders. ${ }^{22}$ The base period formula, especially the thirty-five per cent formula applicable in most cases, ${ }^{23}$ resulted in a drastic reduction of the reinvestment ratio of the AFN, often much below twenty per cent of current earnings. It imposed a heavy burden on AFNs which have low historical allowables. Moreover, the rigid tying of authorized reinvestment to the level of direct investment (or reinvestment) in selected base years in the past did not satisfy the long-term financial needs of corporations in growth situations. ${ }^{24}$ The optional thirty per cent earnings allowable, the possibility of "upstream" adjustments to the historical allowable, ${ }^{25}$ and, beginning in 1970 , the additional forty per cent incremental earnings allowable ${ }^{26}$ will relieve the European subsidiaries of some of these burdens, and give corporate planners more flexibility in their investment decisions.

The authorized maximum reinvestment ratio, however, is still relatively low in many situations. This is not only true with regard to the reinvestment ratio of thirty per cent of the preceding annual earnings (and, assuming increased earnings for the year, of less than thirty per cent of current earnings) under the thirty per cent formula. The incremental earnings method, too, will seldom allow much higher reinvestment ratios. Apart from that, the DI, in electing the applicable formula, will take into account its over-all situation, not necessarily that of a single AFN. Thus, the new formulas somewhat reduce the possibility of a conflict between the regulations and the protection granted minority shareholders under European corporation law, but they do not remove such possibility. For it may still be contrary to European corporation law that a European corporation, by interference of its U.S. parent, is limited to a reinvestment ratio of roughly thirty per cent without regard to its financial needs and investment projects. Therefore, let us turn to an analysis of the corporation laws involved.

U.S.-controlled limited companies are wholly owned; these figures are based on "Wer gehört zu wem?" (7th ed. Commerzbank, 1967 ).

${ }^{22}$ The worldwide minimum quota, now fixed at $\$ 1,000,000$ (OFDI Reg. $\$ 503$, as amended, 34 Fed. Reg. 9066 (1969)), of course will only satisfy the investment needs of small or medium-sized DIs (e.g., of DIs which possess only one or two subsidiaries abroad).

${ }^{23}$ Except for cases of very high average reinvestment or positive net capital transfers to AFNs in r965-66 compared with reinvestment in I964. Cf. statement by L. Hamilton', in Hearings, supra note 9 , at 588 .

${ }^{34}$ See, e.g., statement by Undersecretary of Commerce J. W. Bartlett on the Foreign Direct Investment Program for 1969, U.S. Dep't of Commerce News, Nov. 15, 1968, at 2; statements by Rep. Horton, $\mathrm{II}_{4}$ CoNG. Rec. H882I (daily ed. Sept. 17 , I968); by L. Hamilton, in Hearings, supra note 9, at 588; by C. Stewart, id. at 6r 8; by N. Danielian, id. at 835; furthermore, see Bruck \& Lees, supra note 6, at 47 (with reference to newcomers).

${ }^{25}$ OFDI Reg. $\$ \$ 502,504(\mathrm{~b})$ (c), as amended, 34 Fed. Reg. 9067 (1969).

${ }^{20}$ OFDI Reg. $\$ 506$, as amended, 34 Fed. Reg. 9069 (1969). 


\section{B. Germany}

Under German law one has to draw a distinction between stock corporations and limited companies.

Stock Corporations. In West Germany some very important U.S.-controlled subsidiaries with substantial minority interests have the legal form of a stock corporation (Aktiengesellschaft), which is governed by the stock corporation statute of Ig6 $_{5}$ (Aktiengesetz). ${ }^{27}$ Under this law, the board has discretionary powers to transfer up to fifty per cent of the annual net income of the corporation to the free (or disclosed) reserves (or, in U.S. terminology: to the earned surplus retained for use in the business) until these reserves equal fifty per cent of the corporation's stock. ${ }^{28}$ It is this power of the board with which the repatriation provisions interfere in the first place because they obligate the DI to cause the pay-out and repatriation of more than fifty per cent of the annual earnings. But even if and insofar as the shareholders have power to decide on the transfer to the reserves, ${ }^{29}$ it is very doubtful whether an "excessive" distribution of dividends compelled by the voting power of the parent may not constitute a violation of general principles of corporation law.

True, the power of the board is somewhat modified if a parent corporation actually controls a subsidiary. German law, which has developed a progressive special law of "combines" (Konzern), i.e., parent-subsidiary relationships, recognizes the de facto power of the parent to direct the affairs of the subsidiary. But absent a contract of "domination" between parent and subsidiary, ${ }^{30}$ it provides, in the interest of minority shareholders and creditors, that the parent must compensate the subsidiary for any action taken which is disadvantageous to the subsidiary and which resulted from instructions or any other influence of the parent. If the parent does not, it is liable for damages, except where the board of an independent corporation would have. made the same decision on the basis of sound business principles. ${ }^{31}$ As under American law, ${ }^{32}$ the parent owes a fiduciary obligation to its subsidiary. But the

\footnotetext{
${ }^{27}$ [1965] I Bundesgesetzblatt I089.

${ }^{28}$ Stock Corp. Stat. $\$ 58(2)$.

${ }^{30}$ This is the case with regard to the remaining $50 \%$ of the earnings; it is the case with regard to total earnings where the bylaws provide so, the board (more exactly, the managing board and the supervisory council) cannot reach an agreement, or the reserves have already reached the limit of $50 \%$ of the stock. Stock Corp. Stat. $\$ \$ 58$, r73, I74.

${ }^{30}$ To my knowledge, only two German subsidiaries have concluded such contracts with their respective U.S. parent. The contract of domination, which must be registered in the commercial register, gives the parent the contractual right to direct the affairs of the subsidiary (including its dividend policy) even to the detriment of the latter; the parent must compensate the minority shareholders in advance (at the execution of the contract) for the devaluation of their stock resulting from the future exercise of power. Stock Corp. Stat. $\$ \S 29 I-3$ IO.

${ }^{31}$ Stock Corp. Stat. $\$ 3 I I, 3 I 7$ theoretically are also applicable to wholly-owned subsidiaries. But the parent as sole stockholder can waive the subsidiary's claim for damages, although not with prejudice to the creditors' right to assert this claim. But since the creditors have this right only when the subsidiary is insolvent the parent practically has full powers.

${ }^{33}$ See International Radio Tel. Co. v. Atlantic Communication Co., 290 F. 698 (2d Cir. I923); Veeser v. Robinson Hotel Corp., 275 Mich. I33, 266 N.W. 54 (1936); Sampson Tire \& Rubber Corp. v. Rogan,
} 
standard of conduct probably is stricter under the new German than under American law: it is that of an independent corporation.

There may be some doubt whether the compensation provisions of the new law are at all applicable to the distribution of an "excessive" dividend. Historically, the minority needed protection in the reverse situation of excessive reinvestment. But since the compensation provisions have the purpose of granting the subsidiary growth and development equal to that of an independent corporation, I see no reason why the appropriateness of a parent's direct interference with the board in matters of financial and dividend policy should not be measured by the standard laid down in the new law.

Therefore, in the context of the foreign direct investment regulations we should ask whether an instruction to distribute and repatriate the possibly high amount required by the regulations would inflict a disadvantage on the subsidiary for which compensation must be given. Disadvantage is a very broad notion. It comprises any present and future impairment of the economic situation and of the profitability of the subsidiary, including loss of corporate opportunity, which was caused by the parent's influence. $^{33}$ Since the stock corporation statute is a relatively recent law, it is, however, nearly impossible to make a reliable statement of what constitutes a disadvantage in a specific situation of parent-subsidiary relations.

Keeping in mind this reservation, one may state the following with respect to the repatriation provisions: An "excessive" payout of dividends may force the subsidiary to forego investments which would have appeared appropriate under present and future market condtions, and thereby slow down its growth. ${ }^{34}$ In most cases the rapid growth of the Eurodollar market, the strong supply on the national capital and credit markets, and the relatively favorable capital structure of the European subsidiaries of DIs ${ }^{35}$ has enabled them (or international finance subsidiaries of DIs) to replace retained earnings not authorized under the regulations by raising substantial capital in Europe at favorable rates. Losses of corporate opportunity did not occur; on the contrary, investment of U.S.-controlled subsidiaries has grown also under

136 F.2d 345, (9th Cir. 1942); Chelrob v. Barret, 293 N.Y. 442, 52 N.E.2d 825 (1944); as to the distribution of earnings, see City Bank \& Farmers' Trust Co. v. Hewitt Realty Co., 257 N.Y. 62, I77 N.E. 864 (I934); Dodge v. Ford Motor Co., 204 Mich. 459, I70 N.W. 668 (I9I9).

${ }^{38}$ A. Baumbach, Axtiengesetz $\$ 3$ II n.8 (I3th ed. A. Hueck 1968); I H. Adlen, W. Dünuno \& K. Schmaltz, Rechnungslegung und PrüFung der Axtiengesellschaft $\$ 3 \mathrm{II}$ n.27 (4th ed. Ig68); Gessler, Probleme des neuen Konzernrechts, [1965] DER BETRIEB I730, I731.

${ }^{34}$ As to cases where that happened, see statement by Rep. Mize, Ir4 CoNg. Rec. H8827 (daily ed. Sept. 17, 1968). According to Bruck \& Iees, supra note 6 , at 56 , there are indications that already the voluntary program has slowed down the growth of American overseas subsidiaries. In Ig68, forcign plant and equipment expenditures (excluding Canada) increased only $5 \%$ over the 1967 level. In 1968 , an $8 \%$ rise is expected. See statement by Secretary of Commerce $H$. Stans on the Forcign Direct Investment Program for 1969, U.S. Dep't of Commerce News, April 4, 1969, at 2.

${ }^{35}$ See G. Hufbauer \& F. Adler, Overseas Manufacturing, Investment, and the Balance of PayMENTS I4-I5 (I968). 
the mandatory program. ${ }^{36}$ But here one might have to consider as a disadvantage in the meaning of the German stock corporation statute the lessening of the subsidiary's profits due to higher cost of capital (due to interest) ${ }^{37}$ and the reduction of its possibilities to raise funds in future resulting from the unfavorable change in its capital structure. ${ }^{38}$

Economic theory seems to confirm this result. Although there is much dispute among economists on the relationship between capital structure, the reinvestment ratio, and corporate growth, most of them seem to agree that the possibilities for corporations to raise external funds at any point in time (or to raise them at profitable rates) are limited, and that retained earnings often have to fill the gap in order to finance desirable investment; ${ }^{30}$ retained earnings furthermore expand the corporation's equity base needed for future borrowing. ${ }^{40}$ It follows that there is a close relationship between reinvestment and corporate growth. On the other hand, European corporate management attempts to maintain stable dividends and have them grow continuously, because investors consider dividends to be an index of the profitability of the corporation. ${ }^{41}$ The optimal distribution of corporate income between dividends and retained earnings is a compromise between short-term investment and long-term financial needs. But nevertheless there appears to exist a minimum reinvestment ratio, of course with a broad margin, which a corporation must have to insure a long-term growth rate necessary to maintain its technological and economic efficiency, its position on the market, and its profitability (enterprise value). ${ }^{42}$ This minimum cannot be determined on a general basis since it depends on a variety of factors, including the possibilities for external financing and the profitability of the investment projects of the individual corporation. But it can be

\footnotetext{
${ }^{30}$ See note 34 supra. DIs even did not use their total allowables-a proof for the good capital structure of their AFNs and for the favorable situation on the capital market.

${ }^{37}$ See Bruck \& Lees, supra note 6, at 57 .

${ }^{83}$ See note 24 supra.

${ }^{30}$ Another possibility to fill this gap is the full distribution of earnings and reinvestment to the extent desired by increasing the capital stock of the subsidiary. This possibility, however, is not unlimited (watering of the stock); see Claussen, "Schïtt aus-Hol' zuriick"-kein Generalrezept, [1963] ZEITSCHRIfT für das gesamite Kreditwesen 869; R. Marris, The Economic Theory of Managerial CapITALISM $27(1964)$. Under the regulations, such increases of the subsidiary's capital stock can only be made out of the proceeds of foreign borrowings and are, therefore, not always feasible.

${ }^{10}$ For both functions of retained earnings, see Gutenberg, $\ddot{U} b e r$ den Einfluss der Gewinnverswendung auf das Wachstum der Unternehmen, 35 ZEITschRIFT FüR BETRIEBSWIRTSCHAFT I93 (I963); D. Schneider, Ausschïttungsfähiger Gewinn und das Minimum an Selbstfinanzierung, 20 ZErTSCHRIFT FÜR BETRIEBSWIRTSCHAFTIICHE FoRschung I ( $\mathrm{g} 968$ ); Albach, Zur Finanzierung von Kapitalgesellschaften durch ihre Gesellschafter, xi 8 ZeITschrift FUR diE Gesamte StaAtswissenschaft 654 (1962); Gordon, Security and Investment, Theory and Evidence, I9 J. Finance 607 ( $\mathrm{x}_{94}$ ); Livingstone, Enterprise, Capital and the Growth of the Firm, 17 KrkLos 236 (1964); Lintner, Distribution of Incomes of Corporations Among Dividends, Retained Earnings, and Taxes, 46 Axr. Econ. Rev. (Papers and Proceedings) 97 (1956).

${ }^{1}$ See H. Büschgen, Aktienanalyse und Aktiendewertung Nach der Ertragskraft i8o (I962); H. Kronstein \& C. P. Claussen, Publizität und Gewinnverteilung im neuen Aktienrecht 134 (1960).

\$s Schneider, stipra note 40 , at ro et seq.
} 
determined for a specific corporation. 43 In the individual case it may well be much higher than the roughly thirty per cent that the new formulas of OFDI more or less authorize.

Of course one might argue that a minimum determined according to a given growth rate cannot by itself give the corporation the right to that growth rate. But as far as the board decides on reinvestment it must exercise its business judgment exclusively in the interest of the enterprise, ${ }^{44}$ not in the interest of a single shareholder. To this extent at least, the corporation has a right to grow.

Therefore, it would seem that where the DI compels a dividend leaving the subsidiary a reinvestment ratio below the broad minimum, the DI is obliged to compensate for all the disadvantages indicated above which result therefrom. One might even argue that the same is true where the dividend is below the optimum. The obligation to compensate would only be excluded if the parent can show that the board of an independent corporation, using reasonable care, would have made the same decision as the one compelled by the parent. ${ }^{45}$ Such proof cannot easily be given.

The simplest way for the DI not to come into conflict with the compensation requirement would be to abstain from compelling an "excessive" instead of a normal or appropriate dividend. OFDI, in modification of the "dividend only" rule, now recognizes the transfer of capital by the subsidiary as fulfillment of the repatriation requirement. ${ }^{46}$ But it is doubtful whether the compulsion of the subsidiary to prematurely repay loans given by the DI would not also constitute a disadvantage which must be compensated for by the DI. Another way to meet the requirements of both legal systems would be for the DI to insist on the "excessive" dividend and give the subsidiary compensation by transferring new capital to it. Under the regulations, this can in most cases only be done out of the proceeds of foreign borrowing. In

\footnotetext{
${ }^{43}$ Id. at 2I; of. J. Lindsay \& A. Sametz, Financial Management, An Analytical Approach 323 $\left(\mathrm{Ig}_{3}\right)$.

"Vallenthin, Aktienrechtsreform und Kapitalmarkt, in Marburger Aussprache zur AKTIEnRechtsREFORM 36, 43 (I959).

${ }^{45}$ As for American law, see Sylvia Martin Foundation, Inc. v. Swearingen, 260 F. Supp. 23 I (S.D.N.Y. I966), involving a double derivative suit against Standard Oil of Indiana, its directors, and its whollyowned Luxembourg subsidiary Amoco Oil Holdings, S.A. The complaint charged that Standard's directors had breached their trust duties to Standard in that they had authorized Amoco to float a bond issue outside the United States, and that this has and will cause Standard and Amoco to pay exorbitant rates of interest for the funds so obtained. In a dictum, the court stated:

"[T]he complaint does not plead a claim over which the Court would presume to act involving as it does an attack on a matter of business judgment and policy of defendant's directors in the management of corporate affairs for which, absent an allegation of fraud, personal profit or gain', the undisputed facts show complete justification."

Id. at 235. HUFBAUER \& ADLER, supra note 35 , at 16 , indicate that plaintiff had asserted that the decision to float the bond issue abroad was taken in view of the voluntary program. The court did not mention this. Query whether this would have changed the result.

${ }^{\circ}$ OFDI Reg. $\S 504$ (c)(2) (I968); this provision is maintained by the new amendments, $\$ 1000.504(f)$ (3) (i), 34 Fed. Reg. 9069 (Ig69).
} 
view of the limitations the regulations place on foreign borrowing by DIs or their international finance subsidiaries, ${ }^{47}$ there may be no practical way to give compensation. In such a case the DI must be satisfied with an appropriate dividend.

What is the law regarding the extent to which the shareholders determine the distribution of earnings? Here, it is even more doubtful whether and to what extent the compensation provisions apply. I think the view is untenable that the parent, only because of its control, must exercise its voting power in the interest of the enterprise of the corporation with regard to the total earnings. Retained earnings may increase the parent's risk, and they therefore touch its interest as investor. The new stock corporation statute, by "splitting" the decision on the distribution of earnings, intended to give stockholders more power with regard to reinvestment, i.e., the right to decide in certain cases themselves on the distribution of earnings according to their individual investment preferences. ${ }^{48}$ Therefore, one can argue that the parent is obliged to the interest of the enterprise only with regard to that portion (i.e., fifty per cent until the reserves equal fifty per cent of the stock) on which the board ordinarily decides. Apart from that, only the doctrine of abuse of majority would seem to limit the freedom of the parent in extreme cases ${ }^{48}$ (e.g., extraordinary financial needs of the subsidiary cannot be satisfied on the capital and credit markets under any circumstances).

Limited Companies. The majority of U.S.-controlled subsidiaries in West Germany are in the legal form of a limited company (Gesellschaft mit beschränkter Haftung). The greater part of them are wholly-owned-much more so than among the stock corporations, so the problem of minority protection is perhaps less important here than it is with stock corporations. U.S. investors prefer the limited company because the seventy-five-year-old statute concerning limited companies which governs them ${ }^{50}$ is more flexible and thus more suited for a close corporation.

This is of some significance in our context. The law on limited companies gives the board or shareholders' meeting no power to retain earnings. Such power can only be provided for in the by-laws (and in most cases it is). But it is considered an exception to the legal right of the shareholder to a full distribution of annual earnings, ${ }^{51}$ and it is, therefore, less convincing as a basis for the protection of the

\footnotetext{
${ }^{4}$ OFDI Reg. $\$ \S 324$, I00I-03 (rg68). The main impediment is the certification requirement because European banks prefer to give loans with a 5-year maturity only; see How International Firms Tap the Euro-dollar Market and the Impact of the New U,S. Rules, Bus. INT't, June 21, I968, at 193.

${ }^{4}$ This was one of the most controversial issues in the discussion on the proposed stock corporation legislation. See, e.g., Strauss, Die Rechtsstellung des Aktionärs, in Marburger Aussprache zur AktienRECHTSREFORM I5, 20 et seq. (I959).

${ }^{10}$ See W. Schilling, in 2 Grosskommentar zum Aktiengesetz $\$$ I97 n.13 et seq. (2d ed. C. H. Barz et al. I965); BAUMBAch, supra note $33, \S 243$ nn.7, ro, Ix.

50 [ 1892$]$ Reichsgesetzblatt 477 , as amended; for an American analysis of the law, see De Vries \& Juenger, Limited Liability Contract: The GmbH, 64 Conum. L. Rev. 866 (1964).

${ }^{81}$ M. Hachenburg, GmbH-Gesetz, Einleitung $\$ 29 \mathrm{nn} .3 \mathrm{~b}, 4$ (6th ed. W. Schilling \& W. Schmidt 1956).
} 
company's minority shareholders against "excessive" distribution. Moreover, the protection of minorities in general does not find support in the statute but must be based on the principle of abuse of rights laid down in sections $13^{8}$ and 826 of the Civil Code. $^{52}$ As under stock comporation law, this principle offers a very weak defense which might not be sufficient to overcome the force of the repatriation requirement, at least not of the new formulas.

There is a definite trend in legal literature towards stronger protection of the minority which would amount to some sort of compensation requirement where inappropirate repatriation seriously impairs the interests of the company and of the minority shareholders. ${ }^{53}$ But it is perhaps premature to venture an assessment on the future development of the law. As the law stands now, more can be said in support of the view that the American DI, apart from very extreme cases, will be free to comply with its repatriation obligation.

\section{France}

In France, most U.S.-controlled subsidiaries are in the legal form of a stock corporation (société anonyme) governed by the new company law of 1966.4 This law does not contain special provisions for the protection of minority shareholders. But article 360 of the company law refers to the general principles of contracts law, and it is the general opinion that the court-made principle of abuse of rights-or, as applied to corporations, of abuse of control ${ }^{55}$ - has been retained by the law. ${ }^{50}$

French courts, in a series of decisions dating back to the beginning of this century, have applied this principle in order to annul resolutions of the shareholders' meeting and, more recently, of the board, ${ }^{57}$ or to grant the minority shareholders damages if annullment was inappropriate, where the resolution was not taken in the interest of the corporation but in that of the majority only. The doctrine is particularly applicable to the distribution of earnings, ${ }^{58}$ on which, contrary to German law, the shareholders

\footnotetext{
${ }^{52}$ Judgment of Dec. 14, I959, $3 \mathrm{I}$ BGHZ 258, 277 (dictum); Hachenburg, supra note 5I, at $\$ 45$ n.r5a.

${ }^{\text {ga }}$ J. Wolany, Rechte und Pflichten des Gesellschafters einer GmbH ir4 (1964); B. Fra. von Falkenhausen, Verfassungsrechtliche Grenzen der Mehrheitsherrschaft nach deM Recht der Kapitalgesellschaften $64-65,67$ ( 1967$)$.

EL Loi No. 66-537, [1966] J. O.; [1966] Sem. Jur. III 32197.

${ }^{65}$ Lesourd, L'annullation pour abus de droit des délibérations d'assemblées generales, [1962] REv. TRM. DR. COM. I; Carteron, L'abus du droit et le detournement de pouvoirs dans les assemblées générales des sociétés anonymes, [x964] Revue des societes I67; C. Champaud, LE POUvolr DE CONCENTRATION DE IA SOCIÉTÉ PAR ACTIONS I45 (1962); Contin, L'arret Fruehauf et l'évolution du droit des sociétés [r968] D.S. Jur. 49; and the cases cited by these authors.

${ }^{56}$ G. Ripert, Tratte ElEmentaire de droit commercial Nos. 1221, 1230 (7th ed. Roblot 1968); A. Dalsace, Manual des Societés Anonymes No. $27^{8}$ (4th ed. I967).

${ }^{57}$ Consorts Lavie v. Usines Lavie, Judgment of Jan. 19, 1959, [1959] D. Jur. 260 (Cass. civ. com.).

${ }^{88}$ Cons. Pilier v. Société Chauvin, Judgment of Jan. 20, 1958, [1958] Gazette du Palais I 266 (Cass. civ.); Sté Anciens Etablissements Piquard frères et Durey Sohy réunis, Judgment of April 18, 196r, [196r] Sem. Jur. II I2I64 (Cass. civ. com.); Soc. anon. des Anciens Etabl. Cambier v. Duquesnoy, Judgment of Oct. $16,1963,[1964]$ D. Jur. 431 (Cass. civ. com.); Juris Classeur Sociétés Supp. 142.
} 
alone decide. Although there is no decided case in point, I see, therefore, no reason in principle why the concept of abuse of control should not be applicable to a resolution taken with the votes of the U.S. parent to distribute an "excessive" dividend.

A survey of the decided cases and of legal literature shows, however, that although the concept of abuse of control has been broadened over the decades, it is still a relatively narrow one. French courts refuse to interfere with the business policy of the majority and to replace it by their own judgment. ${ }^{59}$ Actions based on business policy constitute an abuse of control only if they were taken by the majority "contrary to the interest of the corporation and with the sole purpose of deriving an advantage from it to the detriment of the minority." ${ }^{\circ 0}$ "The motivation is decisive. ${ }^{61}$ A resolution is abusive if it is motivated by considerations as to which the interest of the corporation, i.e., of its enterprise, is entirely extraneous. ${ }^{62}$ To this extent, but only to this extent, the enterprise of the corporation has a "right" to exist and a "right" to grow.

This right to grow has been recognized by French courts in cases concerning the massive retention of earnings for reinvestment. ${ }^{63}$ Here, the French Supreme Court ${ }^{64}$ expressly rejected a lower court's ${ }^{65}$ reasoning that the distribution of dividends was the very purpose of the association of shareholders and that the majority could not increase the equity basis of the corporation by retaining earnings. Although the "excessive" pay-out of dividends represents the converse situation, one must say that the right of the corporation to grow is here as much concerned as it is in the case of retaining earnings, and that, therefore, the doctrine of abuse should be applied, all the more so because the interest test constitutes only one element of the concept of abuse of control, the emphasis lying in the motivation of the majority. Of course, how one determines the minimum dividend which could not be attacked under any circumstances raises the same problems as under German law.

Once the applicability of the doctrine of abuse of control to an "excessive" distribution of dividends and the inconsistency of such distribution with the interest of the subsidiary had been established, I would not hesitate to consider the motivation of the DI, namely to comply with its repatriation obligation, to be completely extraneous to the commercial interests of the subsidiary. Such was the holding of the Paris Court of Appeal in the Fruehauf case. ${ }^{66}$ The U.S. Department of Com-

\footnotetext{
${ }^{50}$ Lesourd, supra note 55, at 10; Contin, supra note 55, at 49.

${ }^{00}$ Judgment of April I8, I96r, supra note 58; see Contin, supra note 55, at 49-5I and the cases cited at 50 n.48; note D.B., [196r] Sem. Jur. II 12164.

01 But not in the technical sense of malice.

QD Contin, supra note 55, at 49-50.

${ }^{3}$ See the cases cited supra note 56; cf. Contin, supra note 55, at 51 .

ot Judgment of April i8, I96r, supra note 58.

${ }^{\text {at }}$ Consorts Schumann v. Anciens Etablissements Piquard, Judgment of Feb. 28, 1959, [1959] Sem. Jur. II IIx75 (Cour d'appel, Paris).

${ }^{60}$ Fruehauf-Corporation v. Matardy, Judgment of May 22, I965, [1965] S. Jur. II I4274 bis (Cour
} 
merce, according to a U.S. export control law, had ordered a U.S. parent to instruct its French subsidiary not to perform a contract involving a delivery to Red China. On the request of minority shareholders of the subsidiary the lower court temporarily removed the board of the subsidiary and appointed an administrator in order to make performance possible. The Court of Appeals confirmed, on the ground that nonperformance of the contract would be extremely harmful to the subsidiary, and that, in appointing an administrator, the court had to be guided by the interests of the subsidiary rather than by the personal interests of the majority. The parallel to the regulations is striking; it needs no further comment.

\section{Conclusions}

In conclusion, one may say that the protection afforded minority shareholders under the German and French corporation laws in certain cases constitutes a legal impediment to the repatriation of earnings as required by the regulations, probably even under the recently announced formulas. Just exactly when and to what extent is difficult to state in general terms or even as to a specific subsidiary. Needless to say, the uncertainty of European law and the general approach of OFDI described above almost invite the DI to go as far as possible. And who will oppose the DI? The protection of the shareholders depends on private action. The boards which have the relevant knowledge will hesitate to interfere with the policy of the parent on which they are more or less dependent. This is at least true in the short run. Should the regulations prove to be more than a short-term expediency to cope with a temporary crisis situation, the boards of subsidiaries with substantial minority holdings probably will oppose continuous low reinvestment ratios because they may incur personal statutory liability towards the shareholders. Minority shareholders often are only interested in high dividends and will therefore not object the policy of the parent. But that of course depends on the nature and the amount of their holdings in the subsidiary. In any event they very often do not have the knowledge to be able to prevent the distribution of excessive dividends, and they cannot afford to hire an expert to make a good case.

This is exactly my point: theoretically, or legally, there is no, or only a vague potential, conflict; practically, or in reality, a conflict exists. But, of course, we should not blame the Americans for it. The conflict of European corporation law with a foreign legislation of the type the regulations represent is a new challenge to a body of law that hitherto attempted to cope only with other problems. It is up to the Europeans to give a response.

d'appel, Paris); cf. Contin, stupra note 55, and Note, [1968] D. S. Jur. I48; Rodière, Chroniques de legislation et de jurisprudence francaises-Sociétés commerciales, [1965] REv. TRIM. DR. COM. 610-21. 
II

\section{The European Subsidiary as a Tool of U.S. Foreign Economic Policy Under European Conflicts of Law}

The interests of minority shareholders are not the only European interests affected by the U.S. restrictions. By obliging the American DI to use its power in order to align the financial and dividend policy of its European subsidiaries to its repatriation requirements, the regulations de facto regulate the internal affairs of a corporation which has to live according to European law and is expected to behave like a "good corporate citizen." The regulations attempt to make the U.S. parent, as if it were a "private" agent, enforce U.S. foreign economic policy against the European subsidiaries, thereby affecting European states as such. This is by no means an "imaginary" appraisal, as Americans tend to think; on the contrary, it is a very realistic one looking at the substance of the matter (which, as experience shows, can be best done by those affected by the matter). ${ }^{67}$

In this sense, the regulations are in one line with similar previous attempts of the U.S. to expand the reach of their antitrust and export control law to foreign subsidiaries of U.S. firms. Canada, the country which, due to the control of about forty-five per cent of its industry by U.S. interests, suffers by far the most from such attempts, considers them to be a serious challenge to her sovereignty, political independence, and specific political targets. ${ }^{68}$ However one may regard this characterization, the regulations raise serious problems based on principle which one cannot overlook-even if they have not yet been given much attention in Europe. These problems are primarily of a political nature demanding political action by executive and/or parliament. But that does not mean that legal considerations and court action are inappropriate here. The increasingly political nature of international economic relations and the increasingly commercial nature of international political relations ${ }^{69}$ justify the search for an additional legal response to the admittedly more political problems raised by the regulations. For countries with relatively low U.S. direct investment, such as West Germany and France, court action would perhaps be sufficient to protect the national interest but it would avoid or minimize possible political conflicts with the U.S. Such a legal response should be based on conflicts of law (including substantive law solutions to conflict problems) rather than on international law. ${ }^{70}$

\footnotetext{
${ }^{\circ 7}$ See evaluation in Task Force on the Structure of Canadian Industry, Foreign Ownership and the StRucture of Canadian Industry 3I2-I3 (I968) [hereinafter cited as Canadian Report] and, with respect to the regulations, id. at 336-38. Strong Canadian objections already to the voluntary program (see CaNADIAN REPORT 337-38) seem to have led to the exemption of Canadian subsidiaries from the regulations. OFDI Reg. $\$$ IIOI-07 (1968).

${ }^{\circ}$ See Canadian Report 295 et seq., 310 et seq., 407 et seq.

${ }^{10}$ Wiethölter, Zur Frage des internationalen ordre public, 7 Berichte der Deutschen Gesellschaft Für VöLRERRECHT 133, 135 (1967).

70 The superiority of a conflicts approach is evident in our context: conflicts of law is part of the domestic law subject to interpretation by domestic courts; international law is not.
} 


\section{A. German Law}

Under German law, one might argue that corporation law has already erected a barrier against the exercise of a U.S. parent's control for the purpose of enforcing the foreign economic policy of the U.S. against the subsidiary. The exercise of corporate control is bound to, and limited by, the interest of the "combine," i.e., the interest of the parent (or other subsidiaries) as opposed to the interest of third persons. ${ }^{71}$ Must one not conclude that the DI, in compelling the dividend required by the regulations, does not pursue its own interests but rather the political interests of the U.S., a "third" person outside the combine? I think, however, that a realistic interpretation of the interest test must take into account the surge of international direct investment. Multi-national enterprises which consist of corporations in-

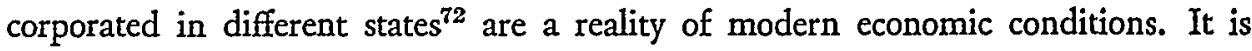
furthermore a reality that it is the parent's management which makes the strategic decisions for the whole enterprise. However the turnover may be spread among the parent and the various subsidiary corporations and whatever may be the extent of decentralization of decision-making-the parent's nationality leaves its mark on the whole enterprise. The multi-nationality in most cases is only of a formal nature. ${ }^{73}$ Actually, we have to deal with a multi-territorially segmented enterprise which derives the advantages of local self-administration and incorporation but avoids their disadvantages by strict obedience to the "common" interest which is unilaterally determined by the parent. If one takes into account the merger between economic and political power one will find genuine multi-nationality only with corporate groups which are beyond the effective reach of national policies because their parent is incorporated under the law of a relatively small country. The U.S.-controlled socalled multi-national enterprise cannot be considered as a giant cosmopolitan "citizen" but only as an institution of the American economic and legal order.

It is to this reality-more exactly: to the American reality-of U.S.-controlled multi-national enterprises that the foreign direct investment regulations attach legal consequences. Therefore, strict opposition by German courts to this attempt would, in my opinion, be only appropriate if such opposition were actually demanded by the general approaches of German conflicts of law (political action of course reserved).

The regulations appear legal under the International Monetary Fund Agreement since they are not concerned with "current" but rather with capital transactions. Whether they could be attacked under general principles of international law is an open question; cf. Note, Limitations on the Federal Judicial Power to Compel Acts Violating Foreign Law, 63 Colum. L. Rev. I44I, 1473 et seq. (1963).

${ }^{71}$ Kropff, Der "faktische Konzern" als Rechtsverhältnis, [1967] DeR BETRIEB 2I 47, 2I52. Whether this requirement is also applicable to the limited company is doubtful.

"The notion of "multi-nationality" is used here in the broadest sense including essentially national corporations operating extra-nationally; for further distinctions, see CANADIAN REPORT 33.

${ }^{73}$ This is a very controversial matter. Cf. Canadian Report 33, 3ri; E. Mandet, DiE EWG und DIE KoNkURRENZ EUROPA-AMERIKA I9-2I (Ig68); Houssiaux, La grande entreprise plutinationale, in L'entreprise et L'économie au XXe siècle 29Y (Bloch-Laîné \& Perroux ed. 1966); Tugendhat, Multinational Companies in the Ascendancy, Financial Times, April 8, 1969, at 13. 
I think that similar considerations are valid here as are entertained in the case of the direct application (recognition) of foreign quasi-public regulatory law, such as exchange control, antitrust, and export control law, in disputes between private parties. ${ }^{74}$ For in both cases we have basically to deal with the problem whether and to what extent a foreign state's regulatory policy may be enforced in German territory-even though from different angles. ${ }^{75}$ The changes in the function of the state, the close relationship between individual and social interests, between economic and political power, the necessity of state planning for the economy, and of economic growth for the state make it more and more inapposite to consider legislative and administrative activity of the state in the economy as an "interference" which must be denied any conflicts of law relevance for the determination of the rights of private parties. Hence, there is a definite trend in German legal literature to apply (recognize), in principle, foreign regulatory law according to its own scope of application, and to be satisfied with controls by German courts over the legitimacy of its scope of application and of its contents. ${ }^{\mathbf{7 6}}$ Our courts are somewhat reluctant to follow this suggestion; ${ }^{77}$ but they have already made the first step in this direction by recognizing foreign regulatory law by applying substantive law to conflicts problems. $^{78}$

In the context of enforcement of foreign regulatory law through exercise of corporate power, this development must be seen together with trends in German business law to replace the dogma of identity between the legal entity and the enterprise with a concept of an "enterprise entity" which may include more than one legal entity. ${ }^{79}$ Although it has not been felt to be appropriate to apply this German

\footnotetext{
${ }^{74}$ Compare A. Ehrenzweig, Confilct of LAwS 503-04 (I962).

${ }^{78}$ In the case of direct application of foreign regulatory law, the question is whether our courts should aid the foreign sovereign in the enforcement of its legislation. Insofar as this is admitted under German law, there is no reason why the DI should not be allowed to enforce a U.S. regulatory policy against its German subsidiary; insofar as this is not admitted, one might, of course, argue that the refusal of "legal aid" does not necessarily exclude the toleration of "private" enforcement. But the reasons underlying such refusal will often be so strong that "private" enforcement should also be barred whenever possible.

${ }^{70}$ Neumayer, Die Notgesetzgebung des Wirtschaftsrechts im internationalen Privatrecht, 2 BERICHTE DER Deutschen Geselischaft für Völkerrecht 35 (1958); R. Bär, Rartellrecht und INTERNationales Privatrecht (I965); Zweigert, Internationales Privatrecht und öffentliches Recht, in FüNFZic JAHRE INSTITUT FUR INTERNATTONALES REchT AN DER UNIVERSTTäT KIEL 224 (I965); Wiethölter, supra note 69, at 160 et seq.; Mertens, Ausländisches Kartellrecht im deutschen internationalen Privatrecht, $3 \mathrm{I}$ RABels Zeitschirift für INTERNationales UNd aüsLANDisches Recht 385 (ig67).

${ }^{77}$ See Judgment of Dec. I7, I959, 3I BGHZ 367; of April I9, I962, [1962] Neue Juristische Wochenschrift I25I (Bundesgerichtshof).

${ }^{78}$ Judgment of Dec. 21, 1960, 34 BGHZ I69; of May 24, x962, [1962] Neue Juristische Wochenschrift 1436 (Bundesgerichtshof): contract between German parties which involved a delivery of U.S. strategic goods to Soviet Russia and hence violated U.S. export control law held contra bonas mores because U. S. controls served maintaining the peace and freedom of the free world; Judgment of Sept. 26, Ig63, [ $\mathrm{Ig} 63$ ] Der Betrieb $\mathrm{I682}$ (Bundesarbeitsgericht): covenant not to compete in a foreign country held unreasonable where illegal under local law.

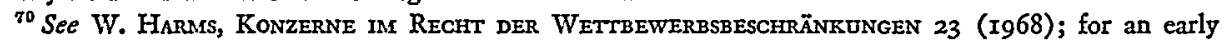
American view, compare Berle, The Theory of Enterprise Entity, 47 CoLum. L. REv. 342 (1947).
} 
concept fully to international entities, it would be anachronistic to oppose the treatment of a multi-national enterprise as a unified enterprise entity by the legislator having jurisdiction over the parent of this entity only because of a desire to enforce our claim of exclusive power over the semi-autonomous (at best) German part of this enterprise.

Instead of an "absolute" prohibition of "private" enforcement of foreign regulatory law by exercise of corporate control, it should suffice to exercise controls over the "abuse" of the foreign sovereign's power. In other words: let us recognize the fact that direct investment in foreign states and the establishment of multi-national enterprises necessarily involves the policies and the legislation of more than one state including those of the home state of the parent, and let us try to see what harm the enforcement of the policies and legislation of that state actually does to our political, economic, and legal interests. ${ }^{80}$ In the domain of law, the concept which may serve as a control is public policy.

Unfortunately, such a functional approach results in new problems for which solutions have yet to be developed. One problem consists in finding a legal basis for the consideration of public policy in corporation law. Public policy is, under German law, a concept of conflicts of law, not of substantive law. It must be integrated into substantive (corporation) law. But probably one can broaden the concept of "good morals" (sections I 38 and 826 of the Civil Code), as our courts have sometimes done ${ }^{81}$ or resort to the principle of "institutional" abuse of rights. ${ }^{82}$ It is, one can argue, contra bonas mores or an abusive exercise of the parent's power over the subsidiary-a power which can be legally exercised only because the new corporation law recognizes it-to use this power not for business purposes but for the enforcement, as a "private" agent, of foreign regulatory legislation inconsistent with our public policy.

The second, more serious problem is the determination of what constitutes a violation of public policy and hence an abusive exercise of corporate control in our context. ${ }^{83}$ First of all, one has to consider the legitimacy of the territorial scope of application or intended effect (extraterritorial effects) of the foreign legislation. ${ }^{84}$ Under general principles of exchange control law, it is not illegitimate for a state to

\footnotetext{
${ }^{80}$ In other words, it is suggested to treat the local subsidiary more or less like a mere branch office as to which the concurring jurisdiction of the host and the home states is recognized.

A somewhat stricter view is maintained by the CANADIAN REPORT 49,338-39. But the Canadian situntion is unique. Apart from that I do not deal here with general political but only with legal approaches to the problem.

${ }^{82}$ Cases cited supra note 78; see furthermore the cases cited by K. SIMITIS, GUTE SitTEN UND ORDRE PUBLIC 55 et seq. (1960).

${ }^{82}$ Raiser, Rechtsschutz und Institutionenschutz im Privatrecht, in SUMmum Jus sUMma INIUnA I49 (Tübingen Ringvorlesung, 1963 ). law.

${ }^{83}$ The criteria should be similar to those applied with respect to the recognition of foreign regulatory

${ }^{84}$ See Neumayer, supra note 76 , at 54 ; BÄr, supra note 76, at 3I8, 359 et seq.
} 
require its citizens to repatriate their property from abroad. ${ }^{85}$ What might be said against the regulations is that they restrict, and intend to restrict, at least de facto, the possibilities of a German corporation to determine its dividend policy according to its business interests. They at least de facto interfere with the internal affairs of the corporation, which-contrary to external affairs-under German conflict of laws are governed by the law of the principal place of business of the corporation. ${ }^{86}$ It is, however, doubtful whether the policy behind the internal affairs rule-uniformity of law and enforcement of the policies of the most interested state-is applicable here. ${ }^{87}$ This would be the case if the shareholder's discretion (including that of a controlling shareholder) had to be kept free from compulsion resulting from foreign law, only because his decisions concern the functioning of a German corporation. The fact that the shareholder's decisions are to a great extent already determined by domestic and foreign tax law supports the opposite view. Moreover, agreements between shareholders on the exercise of their voting rights are legal under German law. ${ }^{88}$ Although, of course, the repatriation requirement is more than mere data for the investor or than a mere contractual obligation, it would seem that its effect on the internal life of the corporation is not so undesirable that the freedom of the shareholder must be protected under any circumstances, i.e., without regard to the contents of the foreign law.

Second, one has to consider the legitimacy of the contents of the foreign law. It is here that we become aware of the dilemma conflict of laws is in when it attempts to leave "the serene atmosphere of private international law." ${ }^{30}$ We have to find out whether the regulations are "congenial" or "foreign," whether they correspond to "an international standard," whether they are "poles apart" from our legal order, "intentionally bellicose," "discriminatory," "reckless," whether they serve "to maintain the peace and freedom of the free world," or whether they are for other reasons in the interest of Germany or not. What are the criteria for such determination? And who is to decide?

The regulations serve the maintenance of international monetary stability and are, therefore, in the interest of all the states of the free world. But is this summary

\footnotetext{
${ }^{85}$ Nor would it seem to be illegitimate for a state to require its citizens to dispose of the control over a foreign corporation. See the antitrust case, United States v. Schlitz Brewing Co., 385 U.S. 37 (1966); contro Canadian Report 329.

${ }^{80}$ See stupra note $I 7$ and accompanying text.

${ }^{87}$ For support for the view that the internal affairs rule is, in principle, also applicable to the exercise of the shareholder's voting right (including the legality of an agreement that limits the exercise of that right), see Judgment of June I7, 1939, I6r Reichsgericht in Zivilsachen 296.

${ }^{88}$ Judgment of May 29, $1967,48 \mathrm{BGHZ}$ I63.

${ }^{30}$ Riphagen, The Relationship Between Public and Private Law and the Rules of Conflict of Laws, I02 I Recueil des Cours de l'Academie de Droit International 2I9, 224 (I96I).

${ }^{\circ 0}$ Zweigert, supra note 76; Neumayer, supra note 76, at 45 et seq.; Wiethölter, supra note 69, at 137 .

${ }^{01}$ Judgment of Dec. 2I, I960, 34 BGHF 169; of May 24, I962, [I962] Neue Juristische Wochenschrift 1436 (Bundesgerichtshof), see supra note 78 .
} 
inquiry, as one might conclude from two German Supreme Court decisions concerning the application of U.S. export control law, ${ }^{92}$ all that the court has to make, perhaps adding, as countervailing factor, the interest of the Federal Republic in freedom of foreign investment? Or must the court consider the appropriateness of the U.S. solution of an international problem from the point of view of the international monetary system and the politico-economic interests of the Federal Republic?

Then the court would probably take into account as positive factors that the regulations tend to remove U.S. pressure for a revaluation of the Deutsche Mark; that they prevented the introduction of U.S. import controls; that by insisting on a strong U.S. engagement in Europe, we are ourselves one source of the U.S. balance of payments problems; and finally, that they may slow down, in the long run, U.S. economic expansion in Europe (strictly a by-product of the regulations, but perhaps a desirable one).

Negative factors probably would be that the regulations possibly only treat symptoms instead of the causes of the present monetary instability; that unilateral action might be inconsistent with the internationality of the problem; ${ }^{03}$ that the increasing demand of U.S. enterprises on the Eurodollar market and national capital and credit markets may overheat the markets and lead to objectionable credit practices; perhaps even our moderate antipathy toward the war in Vietnam, no doubt one of the sources of the present U.S. difficulties.

It is not only doubtful whether, in view of the complex nature of the interests involved and the relationship of such legislation to a concrete situation, a court is capable of making evaluations of this kind, but also whether such evaluations can still be based on judicial reasoning or must be handled politically. ${ }^{94}$ The change of the function of the concept of public policy from a predominantly ethical to a more political defense ${ }^{95}$ drags public policy into the conflict zone between the foreign relations power of the executive, the competence of the democratic legislator, and the judicial power. Can a court decide against the executive and parliament? Can it, if both are in favor of the regulations, hold that they are against public policy? Can it, if both raised protests against the regulations (but did not introduce or enact prohibitive legislation for the time being) hold that the regulations are in accord with public policy? What about a divergency of opinion between executive and parliament? Can a German court still consider the regulations as against public policy after the German Minster of Economic Affairs has approved them in principle, i.e. as the lesser evil compared with U.S. import restrictions?

\footnotetext{
${ }^{22}$ See cases cited supra note 78 .

${ }^{28}$ See Statement by the German Minister of Economic Affairs, supra note 14 , at $\mathrm{x}$ : "However, in the world monetary system such an individual action could be very dangerous for all participants."

24 Cf. Mertens, supra note 76, at 391-92; as for American conficts of law, compare Curric, Notes on Methods and Objectives in the Conflict of Lawus, 1959 DukE L.J. x71, I76.

${ }^{95}$ Wiethölter, supra note 69 , at 137,140 .
} 
German law has not yet developed any solutions to these kinds of conflict. There certainly is no general rule that in matters that vitally concern foreign policy the opinion of the executive has priority. ${ }^{96}$ In two cases concerning the recognition of U.S. export control law ${ }^{97}$ the German Supreme Court had the opportunity to express its view on the matter but the court did not even see the problem. Thus, the regulations confront us with new problems for which the answers have yet to be found. Needless to say, the boards and the minority shareholders of the subsidiary concerned have to assume a responsibility they possibly will not be able to bear. For it is up to them to oppose an instruction by the parent for its inconsistency with German public policy before a court can decide. And how can and will they do so if the whole problem is virtually still virgin land waiting for the legal pioneers?

I am not entirely pessimistic, however. Experience shows that even civil law systems in spite of their usual "cultural lag" are able to meet the challenge of changed social environment. We are about to develop conflict of laws solutions for the increasing commingling of private and administrative law by permitting the application of foreign regulatory law to contracts (outside the lex causae), although exercising controls in case of "abuse." This amounts to the enforcement by German courts of a foreign regulatory policy. All the more one should think that we will be able to develop a system of controls for the situation in which a foreign states does not need the aid of our courts to enforce its policy but can rely on the corporate power of domestic parents to enforce it against their German subsidiaries.

This system of controls should not be a purely political one, leaving the whole burden of defending the German national interests to the executive and to parliament. The goal should be a reasonable division of labor among all three powers. The courts, in applying public policy, should perhaps be limited to considerations that are not completely extraneous to law. They could consider whether the foreign law is "poles apart" from our legal order, whether it is "intentionally bellicose," "reckless," or "discriminatory." But they should not be obliged to consider the actual political situation, specific political disadvantages resulting for the Federal Republic from a foreign regulatory law, or the pure opportuneness of barring the enforcement of this law in Germany.

\section{B. French Law}

Much more must still be done under French law. Apparently there do not exist

\footnotetext{
${ }^{00}$ It appears that under German law the courts are only bound by the recognition of a foreign state by the federal government; here they must apply the private law of that state under the conflicts rules of the forum. They are not bound by nonrecognition but may apply foreign private law. This rule is based on the "unpolitical" nature of private law, the application of which should not depend on highly political matters such as nonrecognition; see L. Ranpe, Internationales Privatrecht i5 et seq. (5th ed. I961); but see Wengler, Fragen der Faktizitat und Legitimitat bei der Anvendung fremden Rechts, Festschrift Lewald 615, 623 (1953).

${ }^{07}$ See note 78 stupra.
} 
"absolute" corporation law barriers which would make an instruction by the parent illegal without regard to the actual harm it does to the subsidiary where it does not serve the interest of the parent but the political interests of a foreign state (although France ordinarily does not enforce its foreign policy goals by making use of the power of French parents over their foreign subsidiaries but rather by relying on bilateral agreements with the host state).$^{98}$ On the other hand, it is also doubtful whether French law could develop easily a conflicts approach to the regulations similar to that envisaged for German law. French conflict of laws still suffers from the aftermath of the French Revolution and the Civil Code which were opposed to the application of foreign law.90 It is only recently that a French court applied foreign regulatory law to a contract governed by a different law. ${ }^{100}$ As long as foreign law is still being considered as a mere fact, the French will probably not be able to recognize that the DI's compliance with the regulations instructing its French subsidiary to distribute the dividend required constitutes a "private" enforcement of a foreign policy as to which the courts should exercise some control.

That French law has not yet reached this stage is best shown by the judgment of the Paris Court of Appeals in the Freuhauf case. ${ }^{101}$ Neither the court in its judgment nor the more "progressive" avocat général Nepveu in his conclusions even mentioned that the U.S. foreign economic policy not to trade with Red China was "poles apart" from French foreign economic policy and that France possibly had an interest that this policy should not be enforced against a French corporation. They were rather satisfied with the enterprise test of the doctrine of abuse of control. Although article 6 of the Civil Code to which article 360 of the new company law refers theoretically would give courts the power to annul a resolution of the board or the shareholders' meeting because of violation of public policy, there is still a long way to go before French courts will apply this concept to the "private" enforcement of foreign regulatory law by a foreign parent corporation. ${ }^{102}$ Of course, the reasoning of the Court of Appeal of Paris may also indicate the desire of French courts to leave the defense of French political interests against "private" enforcement entirely to the executive and to parliament.

\footnotetext{
${ }^{98}$ Such an agreement exists with Belgium with regard to the export of "Mirage" spare parts manufactured by the Belgian subsidiary of Dassault; see Embargo und Souveranität, Frankfurter Allgemeine Zeitung, Jan. 23, 1969 , at 2.

${ }^{90}$ See I. Zajtay, Zur Stellung des ausländischen Rechts im französischen internationalen Privatrecht 46 et seq., 53 et seq., 122-23 (1963).

${ }^{100}$ Spitzer v. Amunategui, Judgment of Jan. 4, 1956 [1956] Revue critique de droit international

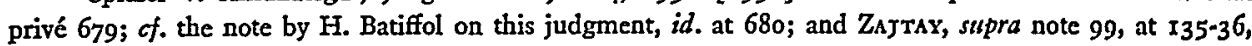
I $41-42$.

${ }^{101}$ Frauehauf-Corporation v. Matardy, Judgment of May 22, I965, [x965] S. Jur. II I414274 bis (Cour d'appel, Paris).

${ }^{102}$ But perhaps one must take into account that it is an old practice of French courts to hide the true reasons of a decision behind rather formal constructions.
} 
III

\section{OUTLOOK}

The problems raised by the U.S. foreign direct investment restrictions are only one aspect of the greater problem of the multi-national enterprise. ${ }^{103}$ To the extent that more and more large firms expand their operations over many countries, conflicts of the kind discussed above will become more frequent-unless states allow these enterprises to live more or less beyond the reach of their national policies and legislation. The problem of the multi-national enterprise has different dimensions dependent on whether the home state is powerful or not in relation to the host state. If it is not, the host state only has to cope with the private power of the multinational enterprise. In general the state will be able to enforce its policies against the multi-national enterprise to the same extent as it does against domestic enterprises. However, with a powerful home state, the private power of the enterprise and the political power of the home state must be added together. To a certain degree, such multi-national enterprise is autonomous; to a certain degree it is not more that an elongated arm of the home state. In this capacity, it sometimes voluntarily acts to promote the political goals of the home state; in any event it can easily be caused by the home state to do so. It is very difficult for the host state to exercise effective controls over the behavior of the multi-national enterprise in such a situation. A state which wants to avoid or minimize the political disadvantages of direct investment originating with powerful foreign states, in particular the partial loss of control over its own economy, will ultimately have to resort to "structural" controls over foreign direct investment. It may require foreign enterprises to apply for an authorization for any acquisition they make within the state, or it may make full use of its antitrust (antimerger) law in order to control foreign direct investment. It is in this context that one must see the discussion at present underway in Europe about U.S. direct investment.

\footnotetext{
${ }^{103}$ Cf. Canadian Report 29 et seq.
} 